Content is licensed under a Creative Commons Attribution 4.0 International Licence elSSN: 2213-0624

\title{
Urban Progress as Noise: a Commentary
}

\author{
Meri Kytö
}

HCM 7: 486-491

DOI: $10.18352 / \mathrm{hcm} .567$

\begin{abstract}
This essay is a commentary on the essays of Annelies Jacobs, Nimrod Ben Zeev and Jens van de Maele. These pieces tackle the theme of urbanization and noise as three separate but intertwined discussions: unwanted sounds in Amsterdam cityscape, loud working conditions in Palestinian limekilns and 'auditory visibility' in offices in Britain and France. Reading the texts in resonance with the aesthetic ponderings of the futurists, one can hear the early-twentieth-century discussions of noise in two ways. Noise was something that needed regulation but at the same time it was the inescapable sign of the modern. Noise as 'nonmusical sound' turns into noise as a disturbance in the system of acoustic communication and into noise as the presence of power, technology and the masses in the urban landscape.
\end{abstract}

Keywords: factory soundscapes, noise, sensory surveillance, urbanization

In I9I4, Italian artists under the direction of Luigi Russolo performed a concert of futuristic music in Milan, a first of its kind. The instruments used in the concert were non-musical, comprising of self-designed sound sources Russolo called intonarumori, 'noise tuners'. As there is no recording of the performance itself (which ended in a riot due to the unorthodox sounds of the orchestra presented as music), we can get a glimpse of how the sounds were organized by looking at the score of the first piece performed, Awakening of the City. In the score each 
cluster of intonarumori is given a line, completed with a time signature and dynamics accompanying the gestural motifs. The instruments are categorized into howlers, cracklers, shufflers, exploders, buzzers, gurglers and whistlers. This music of the future was more than music as a collection of pitches. It was noisy but at the same time well organized and tuned, powerful and technologically new, as if produced by a singing machine of sorts.

The pieces in this special issue tackle the theme of urbanization and noise ('progress in the city') as three separate but intertwined discussions: unwanted sounds in Amsterdam cityscape, loud working conditions in Palestinian limekilns and 'auditory visibility' in offices in Britain and France. Reading the texts in resonance with the aesthetic ponderings of the futurists, one can hear the early-twentieth-century discussions of noise in two ways. Noise was something that needed regulation but at the same time the inescapable sign of the modern. Noise as 'non-musical sound' turns into noise as a disturbance in the system of acoustic communication and noise as the presence of power, technology and the masses in the urban landscape.

Annelies Jacobs deals with the late-nineteenth and early twentiethcentury soundscape of Amsterdam, focusing on the discussion of noise in the public sphere. The study uses non-fiction as primary research material. The palette Jacobs sets for categorizing the sounds described in the writings are (a) sounds that are given negative attention (noise) and (b) sounds that are ignored but can be inferred from the writings. She analyzes the material in terms of the ecology, semiotics and politics of sound. As a result, Jacobs presents a contextualized reading of three periods spanning from I 875 to I945, together with an analysis of the changing sonic environment and how is was understood.

'Cities have always grown noisier' is a trope Jacobs begins with. She underlines the need for historical comparison and concludes with a clear statement that the trope is a 'rhetorical strategy for expressing discontent with the present'. It is indeed a good question to ask whether noise in the public debate is presented as something that can be compared from one situation to another or as a particular problem for certain groups of people. What was the impact of the debate on noise itself to the understanding of environmental and technological relations, to concepts of individual and communal privacy in urban environments, to attention and disturbance in relation to office work and manual labour, 
and so on? Emily Thompson's The Soundscape of Modernity (2002) and Karin Bijsterveld's Mechanical Sound (2008) tackle these questions from different aspects. ${ }^{\mathrm{I}}$ The first studies the effects of engineering and the 'new science' of acoustics, the second the public discussion of noise. As Jacobs writes, it is not enough to pay attention exclusively to sound sources in order to make claims about levels of sound, as the level of sound does not correspond directly to the level of nuisance it creates.

In her conclusion to the essay, Jacobs makes a comparison to present-day discourse on noise. In addition to the moral rationale of the public discussion on noise, the current debate on noise abatement also includes a medicalized argument. Noise is a physical phenomenon that is understood as an actual pollutant: it causes physical damage to living creatures. This evaporation of moral discourse from public talk on noise, especially on the governmental level, may just be temporary, a current fad. The example of the consoling sounds of neighbours in wartime and silences understood as absence tell a parallel story of the importance of a contextual reading of the sonic past and present.

Examining newspaper articles, Jacobs writes that working-class people were less likely to write 'letters to the editor', or at least less likely to get them published. What kind of a forum was the newspaper in early-twentieth-century Amsterdam, and who was its audience? When do people write about sound disturbance in public and what is their motivation in doing so? If noisy people were perceived as irresponsible, what is the structure of class, age and ethnicity behind these sentiments written in the letters? Although Jacobs does not analyze these aspects in this essay, they are important to our understanding of the context of the discussion on noise. It would be helpful also to know the Dutch words that were used in descriptions of the urban ambiance, the 'buzz', the 'roar' and the 'din'. In translating words denoting qualia from one language to another, the significance of the sensory often disappears. The Finnish equivalents for the three words would be humina, pauhu, kuти; such words are linguistically onomatopoeic and their sense is necessarily lost in translation.

In his essay on singing and the health and safety risks of noise at work in the Palestine cement industry between I9I7 and I948, Nimrod Ben Zeev discusses the potentially dangerous spaces of a limekiln. Examining lyrics about work in a limekiln as well as texts published in daily newspapers (the review of the film Metropolis directed by Fritz 
Lang and a letter sent to the children's section together with a drawing of a cement factory), Ben Zeev describes the poetics of danger and wonder. The child's description of the blessed noise of the work done in the factory contrasts with the lyrics describing sounds of danger and with the terrifying sudden silences in the lyrics, demonstrating the importance of understanding the listeners' intention in studying sound and culture.

Ben Zeev invites researchers to find ways to "hear more popular history of sound, related to bodily experience in different manners.' One research group able to respond to his call is the Work with Sounds project, which collects the sound heritage from industrial ambiances, recording the endangered or disappearing sounds of industrial society. ${ }^{2}$ Along with recordings of machines, the project has stirred up recollections of past ambiances among workers, some of which were documented in the workers' handwritten union newsletter Tehtaalainen ('the factory worker'). One recollection of the industrial linen weaving hall at Tampere, Finland, figures as an earwitness to the level of noise produced by the looms and machines, which was so high that most of the young women working there suffered severe loss of hearing after working a few years in the factory. That added to other sensory hardships, such as the heat and stuffiness of the halls.

A question that is difficult to avoid, although Ben Zeev addresses it well, concerns the acoustic specificities of the work songs sung by the cement factory workers. As a soundscape researcher and an ethnomusicologist, I would be interested in figuring out the way the singing might shed light on the situation at the factory. As Ben Zeev observes, the songs were probably sung to pass time and contemplate the arduous working conditions, but did that happen during breaks or was there acoustic room to sing while working? It is not clear from Ben Zeev's account whether singing took place on the industry grounds; it is a hard question to answer, and not immediately relevant to his essay. Moreover, were the songs sung in the presence of others, or were they perhaps sung together? Or were these songs sung outside the factory, fostering empathy for the workers among the larger community? These questions tie into the author's emphasis on the 'necessity of examining sound and the senses in relation to new social realms and situations'.

Jens van de Maele's essay on 'auditory visibility' in nineteenth-century theories on government offices discusses bureaucratic architecture in 
Britain and France. Designing acoustic arenas and understanding their rationales are surprisingly topical and they have interesting history, as the author shows. With regard to the current fashion of constructing open plan offices and adapting public libraries to a clientele less inclined to read there, the concept of 'auditory visibility' is worth thinking about. 'Auditory visibility' has been treated in an article by Tristan Booth and Leland Spencer on managing the aural body rhetoric in public restrooms, in which they call this acoustic arena a panauricon, comparable to Bentham's panopticon as discussed by Foucault. ${ }^{3}$

Controlling acoustic information is one of the many practices that provide the urban dweller (and everyone else for that matter) with a sense of privacy. The right to control information about oneself and the right to secrecy are not self-evident. As van de Maele notes, not many theorists of management and architecture have been interested in the exposure of low-ranked employees to noise. It seems that the levels of secrecy and privacy were hierarchically moderated, as workers who did not perform labour of an intellectual nature were not seen to need a working space free of distraction and interruption.

If such spaces (like the presidio modelo, the panopticon-style prisons in Cuba) had actually been built and taken into use, one wonders which tactics would have been developed by users lower in the surveillance hierarchy, to gain greater privacy? How would they have resisted the distrust of the eavesdroppers on the other end of the 'conversation tubes', had they been installed? This might well be a question to pose in near future, as the use of ubiquitous sensory surveillance gains political momentum.

\section{Notes}

I Emily Thompson, The soundscapes of modernity: Architectural acoustics and the culture of listening in America, I900-1933 (Cambridge MA, 2002); Karin Bijsterveld, Mechanical Sound. Technology, Culture, and Public Problems of Noise in the Twentieth Century (Cambridge MA, 2008).

2 See Sounds of Changes, http://www.soundsofchanges.eu (accessed I May 20I9).

3 E. Tristan Booth and Leland G. Spencer, 'Sitting in Silence: Managing the Aural Body Rhetoric in Public Restrooms', Communication studies (2016), 209-26; DOI: IO.I080/I05I0974.20 I 5. I I 22657. 


\section{About the Author}

Meri Kytö is a researcher in music studies at Tampere University, Finland, and adjunct professor of sound studies at the University of Eastern Finland. She has published on sonic domestication, articulations of acoustic privacy, soundscapes of political protest, busking, football fans and public libraries. Currently she is writing about sensory agency and cochlear implants. E-mail address: meri.kyto@tuni.fi 